\title{
Cardiac Output
}

National Cancer Institute

\section{Source}

National Cancer Institute. Cardiac Output. NCI Thesaurus. Code C119246.

The total volume of blood pumped by the heart over a set period of time, conventionally one minute; it is calculated as heart rate times stroke volume $(\mathrm{CO}=\mathrm{HR} \times \mathrm{SV})$, and is additionally dependent on preload and afterload for functional output. 